Open Access

\title{
Cortisol levels in skimmed milk during the first 22 weeks of lactation and response to short-term metabolic stress and lameness in dairy cows
}

Katharina Gellrich ${ }^{1}$, Tanja Sigl ${ }^{1}$, Heinrich H. D. Meyer ${ }^{1}$ and Steffi Wiedemann ${ }^{2^{*}}$

\begin{abstract}
Background: Cortisol is secreted into blood in reaction to acute stress, but also in phases of diminished feed intake and changed animal behavior. As cows do not always show clear signs of discomfort, reliable diagnostic markers could be used to provide information regarding individual cows' distress. The objective of this study was to establish an ether free immunoassay for the detection of cortisol and to determine values during the first 22 weeks of lactation. Furthermore, the response in milk cortisol levels was assessed during times of metabolic stress and pain associated symptoms of lameness.

Methods: Milk yield and composition, blood serum glucose, NEFA and BHBA as well as milk cortisol were determined in 24 multiparous Holstein-Friesian cows over the course of the first 22 weeks of lactation. Animals were further checked for signs of clinical diseases on a daily basis. Two feed restrictions over three days (FR; $70 \%$ of precious ad libitum intake) were performed during the $4^{\text {th }} w k$ and the $21^{\text {st }} w k$, respectively. An ELISA for cortisol measurement in easily accessible bovine skimmed milk was established and applied.
\end{abstract}

Results: On the last day of FR in early lactation, a reduction in milk yield and changes in serum metabolites compared to respective previous values were detected. The FR in mid-lactation resulted in no changes in milk production and serum metabolites. Milk cortisol was highest during first wk of lactation and remained on comparable levels thereafter. Milk yield and composition were not influenced by FR. Lameness resulted in enhanced milk cortisol levels.

Conclusion: Milk cortisol could be used as an indicator of painful symptoms such as lameness. Higher values of milk cortisol levels during first wk of lactation should be taken into account for interpretation.

Keywords: Cortisol, Dairy cow, ELISA, Feed restriction, Milk

\section{Background}

High-yielding dairy cows have to face immense metabolic challenges throughout the gestation-lactation cycles in their productive lives. The metabolism of dairy cows experiences tremendous alterations around parturition, which involve complex control and feedback regulations of reproductive hormones, of insulin as well as of diminished anabolic with concurrent increased catabolic processes in adipose and muscle tissue $[1,2]$. The onset of lactation exacerbates the energy deficit by direction of glucose to the

\footnotetext{
* Correspondence: swiedemann@tierzucht.uni-kiel.de

${ }^{2}$ Animal Health, Institute of Animal Breeding and Husbandry, Kiel University, Olshausenstr. 40, 24098 Kiel, Germany

Full list of author information is available at the end of the article
}

mammary gland for lactose syntheses resulting in low blood glucose levels [2]. During this critical timeframe of lactation the probability for the occurrence of production diseases is largely increased [3]. The activation of the hypothalamo-pituitary-adrenocortical axis (HPA) is paramount to the cows' physiological endocrine response to stress. In dairy cows pituitary and adrenocortical activity are linked to milk yield, energy balance and plasma concentrations of glucose and non-esterified fatty acids (NEFA) and might be mediated by the cows' individual adaptation process to the negative energy balance [4]. The adrenal steroid hormone cortisol serves as an endpoint in the investigation of HPA-activity. Therefore, the examination of cortisol is considered to be a valuable tool to 
measure stress response [5]. Because cortisol is secreted in a pulsatile fashion with mean pulse intervals of approximately 120 min, single blood samples do not provide adequate information [6]. Thus, cortisol in milk could provide information on the average levels in blood. Concentrations of functional unbound cortisol in milk and plasma are related very closely (0.96) independent of the milk yield. Because binding to globulins prevents passive transfer into milk higher amounts of non-functional bound and total cortisol are found in blood in comparison with milk [7]. Increases of cortisol in blood due to acute stress are reflected by steadily increasing levels in milk which in turn decrease as blood levels do. Therefore, a short peak in cortisol release until $4 \mathrm{~h}$ before milking does not affect its concentration in milk [8]. However, metabolic imbalances during early lactation due to high milk production lead to constant metabolic stress during that period which could be reflected by altered milk cortisol concentration [9]. It has been shown that the measurement of cortisol in cows' milk is an appropriate method to determine the possible stresses of automatic milking, restricted lying or parturient paresis $[10,11]$. Furthermore, pain-associated diseases such as lameness could lead to enhanced cortisol levels.

In this study, an enzyme-linked immunosorbent assay (ELISA) for measurement of cortisol in milk was established. Skimmed milk was used because cortisol has a comparably high solubility in the aqueous fraction of milk [12]. There have been several approaches to this aim via radioimmunoassay or via ELISA with prior ether cortisol extraction. Adopting the protocol of Sauerwein et al. [13], we developed an assay without preceding extraction to measure cortisol directly in readily accessible skimmed milk. This work aimed to determine if metabolic stress due to restricted feeding and acute or chronic stress due to lameness symptoms have an effect on milk cortisol concentration.

\section{Methods}

\section{Experimental cows, housing and feeding}

The experimental design was approved by the animal welfare committee of the Government of Upper Bavaria, Germany (AZ 55.2-1-54-2531-110-09). The study was carried out from August 2009 to January 2011 using 24 multiparous Holstein-Friesian cows kept at the Veitshof Research Farm (Technische Universitaet Muenchen, Germany). The housing and feeding of the multiparous Holstein-Friesian cows are described in Sigl et al. [14]. From d 23 until 31 pp and from d 138 until 146 pp, the cows were moved to a tie-stall with eye contact to the herd, but with separate feeding troughs. During the first three days (d 23 to 25 and 138 to $140 \mathrm{pp}$, respectively), the cows were fed ad libitum and additional concentrates (6.0 and $4.5 \mathrm{~kg}$ during early and mid-lactation, respectively).
From d 26 to 28 and 141 to $143 \mathrm{pp}$, the cows received a restrictive diet and no additional concentrates (70 \% of mean ad libitum energy intake; feed restriction, FR). Fresh feed was mixed daily and the cows were fed half of their daily allotment of the restrictive diet at 0700 and $1700 \mathrm{~h}$. The following three days (d 29 to 31 and 144 to $146 \mathrm{pp}$ ) they were re-fed with ad libitum diet and defined amounts of additional concentrates. During the complete experimental period, fresh drinking water was freely available. After parturition, twice-daily milking was carried out in a $2 \times 2$ tandem milking parlor (GEA WestfaliaSurge $\mathrm{GmbH}$, Boenen, Germany) starting at 0420 and $1540 \mathrm{~h}$. The cows' general health condition was determined every day for clinical signs of disease. Disease was defined as necessary veterinary intervention. In this study, retained placenta (retention $>8 \mathrm{~h}$ ), inflammation of the uterus (discharge of purulent material from the uterus), ketosis (reduced feed intake, declining milk yield and urinary ketone bodies) and mastitis (fever or turgid mammary gland and positive California Mastitis Test) as well as lameness symptoms (change in locomotion) were determined.

\section{Milk sampling}

Milk yield was recorded with electronic milk meters (Metatron P21, GEA WestfaliaSurge GmbH, Boenen, Germany) during each milking. Milk samples for analysis of major milk components were taken on the same respective days of lactation in all animals (twice per lactational wk during the second and third wk pp, thereafter once per wk) as well as before, during and after FR daily on d 23 to 31 and 138 to $146 \mathrm{pp}$, respectively). To obtain a representative sample, aliquots of morning and evening milk were pooled in proportion to the morning and evening milk yield [15], preserved by acidiol and stored at $4{ }^{\circ} \mathrm{C}$ for analysis within $7 \mathrm{~d}$. Milk composition was measured by infrared-spectrophotometry (MilkoScan-FT-6000, VOSS GmbH, Rellingen, Germany) in the laboratories of the Milchpruefring Bayern e. V. (Wolnzach, Germany). Morning milk samples for measurement of cortisol were taken from d 8 pp on twice per wk throughout the experimental period as well as before, during and after feed restrictions on a daily basis ( 23 to 31 and 138 to $146 \mathrm{pp}$, respectively). An $11 \mathrm{~mL}$ aliquot of each sample was stored at $-20^{\circ} \mathrm{C}$ until analysis.

\section{ELISA of cortisol}

Cortisol was determined in skimmed milk by a highly sensitive competitive ELISA [13] with modifications. The coating antibody was obtained from goats immunized against rabbit IgG (Sigma-Aldrich $\mathrm{GmbH}$, Munich, Germany). The second antibody $\left(\mathrm{C}_{1} \mathrm{Pool}_{2}\right.$ Weihenstephan) was raised in rabbits against cortisol-21-hemisuccinate-BSA (Sigma-Aldrich GmbH, Munich, Germany). After affinity purification, the antibodies were diluted in ammonium 
sulfate. Coating of microtiter plates (F96 MikroWell Plates Maxisorb, Nunc, Thermo Fisher Scientific, Langenselbold, Germany) was performed by adding goat IgG anti-rabbit IgG $(1 \mu \mathrm{g} /$ well $)$ dissolved in a coating buffer $(100 \mu \mathrm{L}$; $4.29 \mathrm{~g} / \mathrm{L} \mathrm{Na} \mathrm{CO}_{3} \times 10 \mathrm{H}_{2} \mathrm{O}, 2.93 \mathrm{~g} / \mathrm{L} \mathrm{NaHCO}_{3}$, pH 9.6; Merck KGaA, Darmstadt, Germany). Residual binding sites were blocked with $380 \mu \mathrm{L} /$ well $0.1 \%$ BSA in PBST (phosphate-buffered saline with Tween-20), containing $7.12 \mathrm{~g} / \mathrm{L} \mathrm{Na} \mathrm{NPO}_{4} \times 2 \mathrm{H}_{2} \mathrm{O}, 8.5 \mathrm{~g} / \mathrm{L} \mathrm{NaCl}$ (both Merck KGaA, Darmstadt, Germany), 1 g/L BSA (Serva GmbH, Heidelberg, Germany), deionized water and $\mathrm{HCl}$ until pH 7.2 (Merck KGaA, Darmstadt, Germany). Microtiter plates were stored at $-20{ }^{\circ} \mathrm{C}$ until the day of measurement. The competitive agent was cortisol-21-glucuronide (Steraloids, Newport, USA) labeled with horseradish peroxidase (1:12,000, Roche Applied Science, Mannheim, Germany).

To create standard and control samples with known cortisol concentrations, bulk tank milk was skimmed by centrifugation $\left(3,000 \times \mathrm{g}, 4{ }^{\circ} \mathrm{C}, 15 \mathrm{~min}\right)$. To obtain samples which were free of endogenous cortisol, activated charcoal was added to the tube $(0.7 \mathrm{mg}$ charcoal per $100 \mathrm{~mL}$ skimmed milk). Subsequently, the mixture was shaken horizontally ( $30 \mathrm{~min}, 1,500 / \mathrm{min}$ ) and centrifuged $\left(3,000 \times \mathrm{g}, 4{ }^{\circ} \mathrm{C}, 15 \mathrm{~min}\right)$. Known amounts of cortisol $(0.1$ to $34.5 \mathrm{nmol} / \mathrm{L}$ and 1.0, 2.0, $5.0 \mathrm{nmol} / \mathrm{L}$; Sigma-Aldrich Chemie $\mathrm{GmbH}$, Munich, Germany) were added to the skimmed milk. All experimental milk samples were thawed $\left(37^{\circ} \mathrm{C}, 20 \mathrm{~min}\right)$ and skimmed by centrifugation $\left(3,000 \times \mathrm{g}, 4{ }^{\circ} \mathrm{C}, 15 \mathrm{~min}\right)$.

Duplicate skimmed milk samples or standards $(10 \mu \mathrm{L}$ each) were pipetted to respective coated EIA wells. Enzyme-labeled cortisol $(100 \mu \mathrm{L}$, diluted 1:12,000) and specific antibody $\mathrm{C}_{1} \mathrm{Pool}_{2}(100 \mu \mathrm{L}$, diluted 1:90,000) were added. After over-night incubation $\left(4{ }^{\circ} \mathrm{C}\right)$, the microtiter plates were washed with PBST. In the next step, a substrate solution $(150 \mu \mathrm{L} /$ well $)$ was added which contained equal amounts of substrate A $\left(1 \mathrm{~g} / \mathrm{L} \mathrm{CH}_{6} \mathrm{~N}_{2} \mathrm{O}_{3}, 18 \mathrm{~g} / \mathrm{L}\right.$ $\mathrm{Na}_{2} \mathrm{HPO}_{4} \times 2 \mathrm{H}_{2} \mathrm{O}, 10.3 \mathrm{~g} / \mathrm{L} \mathrm{C}_{6} \mathrm{H}_{8} \mathrm{O}_{7} \times \mathrm{H}_{2} \mathrm{O}, \mathrm{pH}$ 5) and substrate $\mathrm{B}(500 \mathrm{mg} / \mathrm{L}$ tetramethylbenzidine (TMB), $40 \mathrm{~mL} / \mathrm{L}$ DMSO, $10.3 \mathrm{~g} / \mathrm{L} \mathrm{C}_{6} \mathrm{H}_{8} \mathrm{O}_{7} \times \mathrm{H}_{2} \mathrm{O}, \mathrm{pH}$ 2.4). Sigma-Aldrich Chemie $\mathrm{GmbH}$ (Munich, Germany) provided $\mathrm{TMB}$ and DMSO and all other chemicals were purchased from Merck KGaA (Darmstadt, Germany). Horseradish peroxidase cleaves hydrogen peroxide in $\mathrm{OH}-$ radicals, which react with the amino-group of TMB, resulting in blue TMB-cations. After incubation in the dark (room temperature (RT), $40 \mathrm{~min}$ ), enzymatic reaction was stopped by addition of $2 \mathrm{M} \mathrm{H}_{2} \mathrm{SO}_{4}(50 \mu \mathrm{L} /$ well), followed by protonation of the TMP-radicals, which resulted in a color change to yellow. Extinction was measured photometrically at $450 \mathrm{~nm}$ (Sunrise microplate reader). Standard curves as well as concentrations of cortisol in skimmed milk were determined with the Magellan data analysis software (both Tecan Group Ltd, Maennedorf, Switzerland).

\section{Blood sampling}

Blood samples were taken twice before expected parturition (d 7 and 14 ap), on d 1, 8, 15, 22, 43, 113 pp and at last day of trial (d $155 \mathrm{pp}$ ). Additional blood samples were collected one day before, all days of and three days after FR (d 26, 27, 28, 29 and 32 pp as well as d 141, 142, 143, 144 and $147 \mathrm{pp})$. Blood samples were obtained in the morning after milking, but before feeding and processed as described in Sigl et al. [14]. Measurements of serum metabolites were conducted at the laboratories of the Clinic for Cattle of the University of Veterinary Medicine (Hannover, Germany) as described in Sigl et al. [14].

\section{Statistical analysis}

Energy balance was calculated using the formula $\mathrm{EB}=(\mathrm{DMI}$ diet $\times$ NEL diet $)+($ DMI concentrates $\times$ NEL concentrates $)-\left(0.293 \times\right.$ body weight $\left.{ }^{0.75}\right)-(0.38 \times$ milk fat concentration $)-(0.21 \times$ milk protein concentration $)+0.95) \times$ milk yield) as described by Kamphues et al. [16]. Energycorrected milk yield was obtained with the equation ECM $(\mathrm{kg})=($ milk yield $\times 0.327)+($ milk fat yield $\times 12.86)+($ milk protein yield $\times 7.65)$ and fat-corrected milk yield with the equation $\mathrm{FCM}(\mathrm{kg})=($ milk yield $\times 0.4)+($ milk fat yield $\times 15$ ).

SAS (Version 9.2, SAS Institute Inc., Cary, NC, USA) was applied for statistical analyses. All milk and blood data were compared using the Mixed procedure with the covariance structure which fit best according to the Aikaike information criterion [17]. 'Day in milk, 'season of sampling' (4 classes: spring, summer, autumn, winter),' 'parity' (two classes: $2, \geq 3$ ) and 'occurrence of lameness symptoms' (no lameness, lameness) were included as fixed effects. The 'ECM' was considered to be a covariate. The 'cow' was included as a random effect. For analyses of DMI, energy intake and energy balance each FR-period was analyzed separately including the fixed effects 'day in milk' and 'parity' and the random effect 'cow'. If an overall significant effect was found, subsequent Bonferroni posthoc analyses were performed. Simple correlations were calculated using the Proc corr statement in SAS. A Pvalue of $<0.05$ was considered significant. Data are presented as least square means (LSM) \pm standard error (SE).

\section{Results}

Milk production and key blood metabolites during first 155 days of lactation

The lactation curve patterns for milk yield, milk protein and milk fat were comparable to the previously reported results of selected time points by Sigl et al. [18]. Regarding the blood serum parameters, glucose showed the highest levels at day of parturition $(4.75 \pm 0.15 \mathrm{mmol} / \mathrm{L})$ and declined until d 8 pp $(3.67 \pm 0.14 \mathrm{mmol} / \mathrm{L} ; P<0.01$; Fig. 1). After d $43 \mathrm{pp}$, glucose leveled at approximately $4.0 \mathrm{mmol} / \mathrm{L}$. In most of the cows $(n=13)$ maximum 


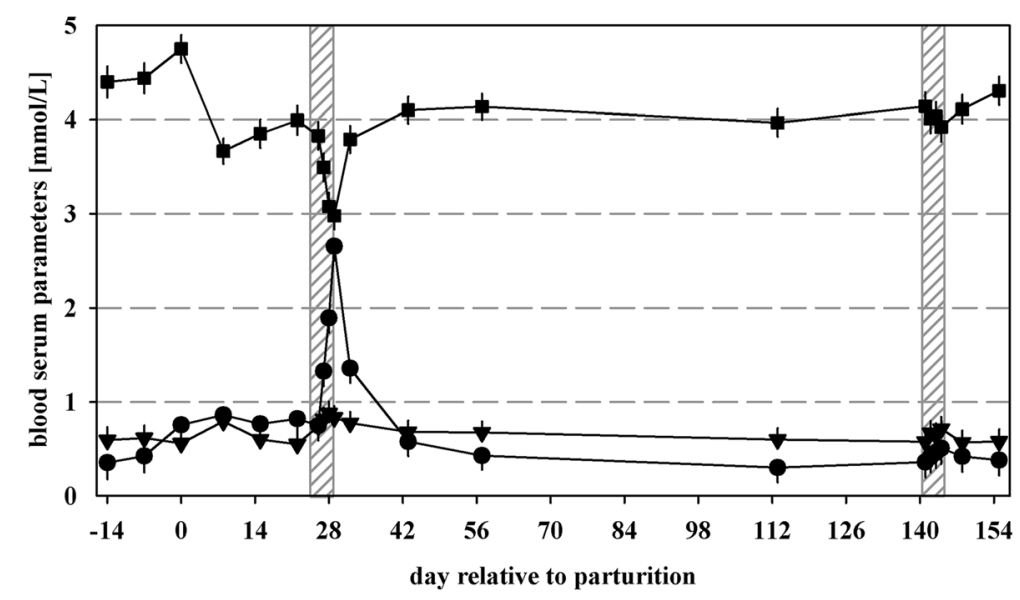

Fig. 1 Concentration (mmol/L) of glucose $(\mathbf{-})$, non-esterified fatty acids (NEFA; $\mathbf{\nabla})$ and $\beta$-hydroxybutyrate $(B H B A ; \bullet)$ in blood serum of multiparous cows during the experimental period. Grey shaded areas indicate three days before, three days of and three days after feed restrictions (70\% of previous ad libitum energy intake) during early (d 23-31 pp) and mid-lactation (d 138-146 pp). Values are presented as LSM \pm SEM

NEFA concentrations $(>1.0 \mathrm{mmol} / \mathrm{L})$ were measured at d 8 pp. Blood serum beta-hydroxybutyrate (BHBA) increased in 19 cows after parturition above $0.5 \mathrm{mmol} / \mathrm{L}$ and reached maximum levels at $\mathrm{d} 8 \mathrm{pp}$.

\section{Feed parameters, milk production and key blood metabolites during metabolic challenges}

Although cows were accustomed to a cubicle housing system, no effects on behavior, such as excessive vocalization or restlessness, were detected due to tying of animals. During both FRs DMI, energy intake and energy balance were reduced as described in Sigl et al., [18]. Milk yield declined during restricted feeding in early lactation by $4.6 \mathrm{~kg}$ $(P<0.01)$, whereas ECM did not differ during both FRs. Milk protein and milk fat were not influenced by FRs. Serum glucose levels dropped during FR in early lactation below $3.0 \mathrm{mmol} / \mathrm{L}$, but increased during subsequent ad libitum feeding $(P<0.001$; Fig. 1$)$. Blood NEFA values were not affected by both FRs. From d 26 to 29 pp, concentrations of BHBA increased to values of $2.65 \pm$ $0.16 \mathrm{mmol} / \mathrm{L}(P<0.001)$. Thereafter, BHBA levels decreased in all cows, but did not reach initial values $(P<$ 0.01). During FR in mid-lactation, no increases in blood serum NEFA and BHBA levels were measured.

\section{Clinical signs of diseases}

Lameness was diagnosed at least once in 14 animals prior and after parturition (d -14 until d 143 pp; total $54 \mathrm{~d}$ ). Most changes in locomotion were caused by heel-horn erosions (52\% of detected lamenesses) and the digital dermatitis complex (31 \%). Lower proportions of lamenesses were caused by sole ulcers (9\%), tarsitis (5\%) and peritarsitis (2\%). Retained placenta or inflammation of the uterus were seen in 8 animals (d 1 until d $22 \mathrm{pp}$ ) and mastitis was diagnosed in 6 animals throughout lactation (d
21 until d $148 \mathrm{pp}$ ). Clinical signs of ketosis were seen in 3 cows mainly during early FR (d 8 and d 29 to $31 \mathrm{pp}$ ). Because the number of days with disease symptoms other than lameness was low these diseases and respective cortisol values were not included in the analysis.

\section{Cortisol in skimmed milk}

Inter-assay and intra-assay coefficients of variability of all measurements (46 microtiter plates) were acceptable (12.6 and 6.7, respectively). Between 1 and $10 \mathrm{nmol}$ cortisol per L skimmed milk a high accuracy of the ELISA method was determined. The recovery rate of the test was 105.3, 102.5 and $111.2 \%$ for control samples with 1, 2 and $5 \mathrm{nmol} / \mathrm{L}$ cortisol in skimmed milk. The cross-reactivity of the test was determined for cortisol (100\%), prednisolone (26.6\%), 11ß-hydroxy-progesterone (20.9\%), cortisone (15.1\%), corticosterone (13.9\%), prednisone (8.5\%), progesterone $(4.5 \%)$, aldosterone (1.9\%), testosterone $(1.5 \%)$, betamethasone $(0.6 \%)$ and pregnenolone $(0.2 \%)$. Cross-reactivity for dexamethasone, estradiol-17 $\beta$ and cholesterol was below $0.1 \%$.

The morning milk cortisol concentration in skimmed milk was effected by the day in milk $(P<0.05$; Fig. 2$)$. Highest concentrations were observed during the first wk of lactation $(5.8 \pm 0.48 \mathrm{nmol} / \mathrm{L})$. Thereafter, the weekly values were comparable (between 3.6 and $6.2 \mathrm{nmol} / \mathrm{L}$ ). Second parity animals displayed in trend lower milk cortisol concentrations in comparison with higher parity animals $(4.59 \pm 0.27$ vs. $5.15 \pm 0.28 \mathrm{nmol} / \mathrm{L} ; P=0.07)$. Concentrations of milk cortisol were not elevated after moving the animals to a tie-stall barn on d 23 and $137 \mathrm{pp}$, respectively (Fig. 2). Also, restricted feeding did not affect milk cortisol levels (Table 1). Higher cortisol concentrations were analyzed in morning milk of lame cows in comparison with concentrations of sound cows $(3.69 \pm 0.16$ vs. $6.05 \pm$ 


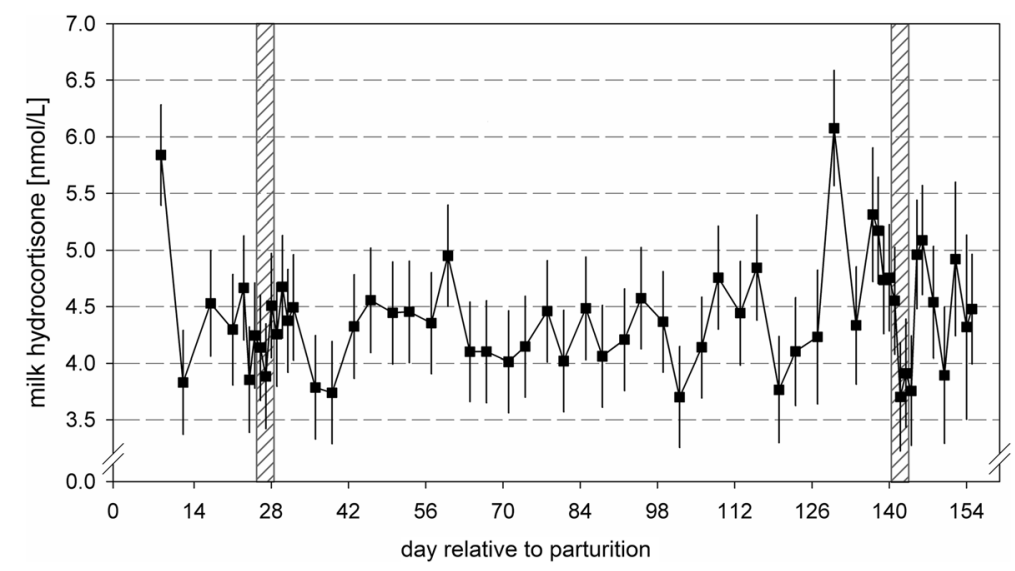

Fig. 2 Cortisol (nmol/L) in skimmed milk of multiparious cows during the experimental period. Grey shaded areas indicate three days before, three days of and three days after feed restrictions (70\% of previous ad libitum energy intake) during early (d 23-31 pp) and mid-lactation (d 138-146 pp). Values are presented as LSM \pm SEM

$0.38 \mathrm{nmol} / \mathrm{L}$ for sound and lame cows; $P<0.01)$. Simple correlations between milk cortisol and other parameters revealed a low negative relationship to yields of milk $(-0.170)$, protein $(-0.134)$ and fat $(-0.091 ; P<0.01)$. Low positive correlation could be observed between milk cortisol and protein concentration $(0.096, P<0.01)$. Furthermore, blood serum NEFA levels were positively correlated to amounts of milk cortisol $(0.149, P<0.05)$.

\section{Discussion}

Metabolic transformation processes for preparation of parturition and lactation already take place during the prepartal transition period, reflected among other things by enhanced gluconeogenesis and fat mobilization

Table 1 Mean cortisol in skimmed milk (LSM) at three days before, three days of and three days after feed restriction (70\% of previous ad libitum intake) in early and mid-lactation

\begin{tabular}{|c|c|c|c|c|c|}
\hline \multirow[t]{2}{*}{$\begin{array}{l}\text { Relative } \\
\text { to FR }\end{array}$} & \multicolumn{2}{|c|}{$\begin{array}{l}\text { FR in early lactation } \\
(n=24)\end{array}$} & \multicolumn{2}{|c|}{$\begin{array}{l}\text { FR in mid-lactation } \\
(n=22)\end{array}$} & \multirow[t]{2}{*}{$\mathrm{RSD}^{\mathrm{a}}$} \\
\hline & $\mathrm{DIM}$ & $\begin{array}{l}\text { Cortisol, } \\
\mathrm{nmol} / \mathrm{L}\end{array}$ & $\overline{D I M}$ & $\begin{array}{l}\text { Cortisol, } \\
\mathrm{nmol} / \mathrm{L}\end{array}$ & \\
\hline \multirow[t]{3}{*}{ Before } & 23 & 4.67 & 138 & 5.17 & \multirow[t]{9}{*}{1.86} \\
\hline & 24 & 3.85 & 139 & 4.74 & \\
\hline & 25 & 4.24 & 140 & 4.76 & \\
\hline \multirow[t]{3}{*}{ During } & 26 & 4.14 & 141 & 4.55 & \\
\hline & 27 & 3.88 & 142 & 3.70 & \\
\hline & 28 & 4.51 & 143 & 3.91 & \\
\hline \multirow[t]{3}{*}{ After } & 29 & 4.25 & 144 & 3.76 & \\
\hline & 30 & 4.68 & 145 & 4.96 & \\
\hline & 31 & 4.38 & 146 & 5.09 & \\
\hline
\end{tabular}

FR feed restriction, DIM day in milk, day relative to parturition, $R S D$ residual standard deviation, ECM energy corrected milk yield ${ }^{a}$ Residual standard deviation was calculated by extracting the square root of the residual
[19]. In the present study, blood serum glucose showed the highest levels at day of parturition, due to the physiological high blood glucose levels during calving [20]. In agreement with Piechotta et al. [21] who showed an association of prepartum high NEFA values and postpartum development of production diseases three cows with an increased blood NEFA concentration were also affected by retained placenta, recumbency or ketosis after parturition in our study. Also, most of the cows reached critical ( $>1.0 \mathrm{mmol} / \mathrm{L}$ ) [22] and maximum NEFA levels in wk 2 pp. Thereafter, NEFA values declined constantly [9]. Three cows showed blood serum BHBA levels above threshold values of $1.2 \mathrm{mmol} / \mathrm{L}$ after parturition [23].

A FR in early lactation led to an enhancement of the metabolic challenge in all cows which is reflected by changes in metabolic key metabolites. Blood serum glucose levels dropped below critical values of $3.0 \mathrm{mmol} / \mathrm{L}$ indicating insufficient energy supply [24, 25]. Blood serum NEFA levels increased only numerically, whereas BHBA concentrations rose above threshold values for subclinical ketosis of $1.2-1.4 \mathrm{mmol} / \mathrm{L}$ [3]. In mid-lactation lower serum NEFA and BHBA levels in concordance with a sustained physiological serum glucose concentration suggest a more stable metabolic status during that time period.

In the present study we developed a sensitive ELISA for measuring cortisol in milk without previous ether extraction. The ELISA exhibited a high analytical sensitivity, low imprecision, low cross-reactivity and satisfactory analytical recovery. Cortisol levels found in our study are not directly comparable to values described in literature as they vary highly between applied methods (ethylacetate extraction vs. measurement in skimmed milk and radio-immunoassay or RIA $v s$. ELISA, free $v s$. total cortisol measurement). Further differences between test methods are due to variation in specificity, sensitivity 
and cross-reactivity with structural related compounds. However, average cortisol concentrations are within the range of values which were previously observed in cows (0.5 to $11.7 \mathrm{ng} / \mathrm{mL}$ ) [8].

Earlier studies have reported that cortisol levels are elevated in early $(1.63 \mathrm{nmol} / \mathrm{L})$ compared to later stages of lactation $(0.69 \mathrm{nmol} / \mathrm{L})$ [26] which is in agreement with our results. Hence, results of milk cortisol measurements during the first wk of lactation should not be included in the assessment of cows' well-being. Thereafter, values do not differ and outliers which are potentially due to distress could be detected by measuring milk cortisol.

Changing of the housing conditions by tethering of the animals in a separate area of the barn was unknown to all animals particularly in early lactation. However, no rise in concentrations of milk cortisol was examined in milk samples after separation. This could be due to the fact that the cows were moved after morning milking and quickly adapted to the altered environment. A return of cortisol secretion to basal levels has been shown to occur within 24-48 h after tethering of bulls [27]. Also, short-time restricted feeding did not result in variation of milk cortisol levels. It was previously reported that high milk yield $(11,443 \mathrm{~kg}$ fat and protein-corrected milk in preceding $305 \mathrm{~d}$ lactation) and associated assumed large energy deficits $(-82 \mathrm{MJ}$ in ongoing lactation; [4]) as well as ketosis (blood serum BHBA > $1.5 \mathrm{mmol} / \mathrm{L}$ ) [10] are correlated to lower cortisol levels. Fisher et al. [11] observed no effects of moderate FR ( $3 \%$ vs. $4 \%$ of body weight of dry matter daily for $7 \mathrm{~d}$ ) on cortisol levels, supporting our findings. Our results indicate that a reduced feed intake over a short period of time does not lead to a stress response involving HPAactivation and increased cortisol secretion.

Basal blood levels of cortisol are elevated in cows which are not allowed to lie down (from 15:00 to 06:45 over $7 \mathrm{~d}$ ) [11], whereas in ketotic cows, cortisol blood levels are lower $(9.6 \mathrm{nmol} / \mathrm{L})$ compared to cows with mastitis $(23.3 \mathrm{nmol} / \mathrm{L})$ or recumbent animals $(96.7 \mathrm{nmol} / \mathrm{L})$ [10] This trend could also be observed in our animals, however, due to the very low number of three animals showing clinical signs of ketosis our finding must be interpreted very carefully. Severe pain related chronic diseases have been shown to increase hair cortisol levels in humans [28]. An increase in milk cortisol could also be demonstrated in our study in animals which showed signs of distress such as lameness. Lameness is one of the most serious welfare problems faced by dairy cows. In this study, cows were not selected due to occurrence of diseases symptoms. Nevertheless, lameness symptoms were seen more often than the reported prevalence of approximately $48 \%$ in 33 conventional free stall barns in Germany [29]. This might be due to the fact that the general health of the animals was checked daily by the researchers and clinical signs were reported and treated immediately. Due to the low number and different underlying causes of changes in locomotion in this study no further analysis was performed on the discrimination power for milk cortisol measurements between lame and non-lame animals. In this regard, existing information on the effect of lameness on cortisol levels in plasma and milk of cows is inconsistent. For instance, O'Driscoll et al., [30] reported that cows with lameness caused by sole ulcers displayed higher blood cortisol levels compared with healthy cows. On the contrary, Almeida et al. [31] and Walker et al., [32] detected no significant difference in cortisol levels in blood or milk between lame and sound cows, although numerical differences were stated (up to $43 \%$ higher values in lame animals). The detectability of a distinct increase in milk cortisol in lame animals might be related to the underlying cause and duration of the distress. In this regard, Almeida et al., [31] and O'Driscoll [30] proposed the use of the ratio between cortisol and dehydroepiandrosterone (DHEA) as a marker of inflammation. However, to the authors' knowledge the only methods described so far to detect DHEA in milk is liquid chromatography-tandem mass spectrometry which is labor intensive and expensive [33].

High circulating cortisol concentrations were reported to be linked to reduced milk yields [34]. However, Fukasawa et al. [35] reported a weak positive correlation between daily milk yield and milk cortisol $(0.13)$ which could not be confirmed by our results. The correlation analyses indicated a significant negative association of milk cortisol and milk yield and milk yield dependent variables (i. e. protein yield and fat yield). However, the respective biological meanings of the small correlations are questionable, particularly in context of inconsistent earlier reported results. Cortisol levels were not found to be negatively correlated to milk composition such as protein $(-0.33$; [35]) and milk fat concentration $(-0.28$; [26]). The positive trend between blood glucose and milk cortisol supports results of Breves et al. [36] who found a positive correlation between blood glucose and blood cortisol (0.18). However, the documented negative correlation between blood ketone bodies and cortisol $(-0.31$; [36]) could not be established in our study.

\section{Conclusion}

Milk cortisol concentration was higher during first wk of lactation, but was not influenced by tethering animals and restricted feeding in this study. It could act as an easily accessible diagnostic marker of painful events such as lameness, independent of its underlying cause, but further studies on the validation of the prospective potential of this parameter with a higher number of animals and disease cases are needed. 


\section{Abbreviations}

BHBA: Beta-hydroxybutyrate; FR: Feed restriction; HPA: Hypothalamopituitary-adrenocortical axis, NEFA, non-esterified fatty acids.

\section{Competing interest}

The authors declare that they have no competing interest.

\section{Authors' contributions}

KG acquired the data and did most of the analysis and interpretation of data. She drafted the manuscript. TS helped in the acquisition and analysis of samples and data. HM contributed greatly to the conception and design of the study, but unfortunately passed away before writing of the manuscript. SW did most of the conception and design of the study, helped with the interpretation of data and revised the manuscript. All authors read and approved the final manuscript.

\section{Acknowledgements}

We gratefully appreciate the laboratory assistance of Waltraud Schmid and Stefanie Dommel for establishing the ELISA and analyzing of the samples. Furthermore we like to thank Sachsenmilch GmbH, the Bavarian Ministry for Food, Agriculture and Forests and the Association for Support of Dairy Research at TU Munich for financial support.

\section{Author details}

'Physiology Weihenstephan, Technische Universitaet Muenchen, Weihenstephaner Berg 3, 85354 Freising, Germany. ${ }^{2}$ Animal Health, Institute of Animal Breeding and Husbandry, Kiel University, Olshausenstr. 40, 24098 Kiel, Germany.

\section{Received: 19 December 2014 Accepted: 20 July 2015}

\section{Published online: 04 August 2015}

\section{References}

1. Ingvartsen $\mathrm{KL}$, Andersen JB. Integration of metabolism and intake regulation: A review focusing on periparturient animals. J Dairy Sci. 2000;83:1573-97.

2. Bell AW, Bauman DE. Adaptations of glucose metabolism during pregnancy and lactation. J Mammary Gland Biol Neoplasia. 1997;2:265-78.

3. LeBlanc S. Monitoring metabolic health of dairy cattle in the transition period. J Reprod Dev. 2010;56(Suppl):S29-35.

4. Beerda B, Kornalijnslijper JE, van der Werf JTN, Noordhuizen-Stasen EN, Hopster $\mathrm{H}$. Effects of milk production capacity and metabolic status on HPA function in early postpartum dairy cows. J Dairy Sci. 2004;87:2094-102.

5. Mostl E, Palme R. Hormones as indicators of stress. Domest Anim Endocrinol. 2002;23:67-74.

6. Lefcourt AM, Bitman J, Kahl S, Wood DL. Circadian and ultradian rhythms of peripheral cortisol concentrations in lactating dairy cows. J Dairy Sci. 1993;76:2607-12

7. Fox L, Butler WR, Everett RW, Natzke RP. Effect of adrenocorticotropin on milk and plasma cortisol and prolactin concentrations. J Dairy Sci. 1981;64:1794-803.

8. Verkerk G, Phipps A, Carragher J, Matthews L, Stelwagen K. Characterization of milk cortisol concentrations as a measure of short-term stress responses in lactating dairy cows. Anim Welf. 1998;7:77-86.

9. Grummer RR, Mashek DG, Hayirli A. Dry matter intake and energy balance in the transition period. Vet Clin North Am Food Anim Pract. 2004:20:447-70.

10. Forslund KB, Ljungvall OA, Jones BV. Low cortisol levels in blood from dairy cows with ketosis: a field study. Acta Vet Scand. 2010:52:31.

11. Fisher A, Verkerk G, Morrow C, Matthews $L$. The effects of feed restriction and lying deprivation on pituitary-adrenal-axis regulation in lactating cows. Lives Prod Sci. 2002;73:255-63.

12. Butler WR, Des Bordes CK. Radioimmunoassay technique for measuring cortisol in milk. J Dairy Sci. 1980:63:474-7.

13. Sauerwein H, Dursch I, Meyer HH. Quantitation of glucocorticoid receptors in bovine skeletal muscle: topographical distribution, sex effect and breed comparisons. J Steroid Biochem Mol Biol. 1991;39:941-5.

14. Sigl T, Gellrich K, Meyer HHD, Kaske M, Wiedemann S. Multiparous cows categorized by milk protein concentration and energy-corrected milk yield during early lactation metabolism, productivity and effect of a short-term feed restriction. J Anim Physiol Anim Nutr. 2013;97:278-96.
15. Quist M, LeBlanc S, Hand K, Lazenby D, Miglior F, Kelton D. Milking-to-milking variability for milk yield, fat and protein percentage, and somatic cell count. J Dairy Sci. 2008;91:3412-23.

16. Kamphues J, Coenen M, Kienzle E, Pallauf J, Simon O, Zentek J. Supplemente zu Vorlesungen und Übungen in der Tierernährung. 10th ed. Hannover: M. \& H. Schaper Alfeld; 2004

17. SAS. SAS. In: Book SAS. 91st ed. Cary, USA: SAS Institute Inc; 2002.

18. Sigl T, Meyer HHD, Wiedemann S. Gene expression analysis of protein synthesis pathways in bovine mammary epithelial cells purified from milk during lactation and short-term restricted feeding. J Anim Physiol Anim Nutr. 2013:98:84-95

19. van Dorland HA, Richter S, Morel I, Doherr MG, Castro N, Bruckmaier RM. Variation in hepatic regulation of metabolism during the dry period and in early lactation in dairy cows. J Dairy Sci. 2009;92:1924-40.

20. Silva-del-Río N, Fricke PM, Grummer RR. Effects of twin pregnancy and dry period feeding strategy on milk production, energy balance, and metabolic profiles in dairy cows. J Anim Sci. 2010;88:1048-60.

21. Piechotta M, Sander A, Kastelic J, Wilde R, Heppelmann M, Rudolphi B, et al. Short communication: Prepartum plasma insulin-like growth factor-I concentrations based on day of insemination are lower in cows developing postpartum diseases. J Dairy Sci. 2012:95:1367-70.

22. Chapinal N, Carson M, Duffield TF, Capel M, Godden S, Overton M, et al. The association of serum metabolites with clinical disease during the transition period. J Dairy Sci. 2011;94:4897-903.

23. Duffield TF, Lissemore KD, McBride BW, Leslie KE. Impact of hyperketonemia in early lactation dairy cows on health and production. J Dairy Sci. 2009;92:571-80.

24. Nielsen $\mathrm{NI}$, Ingvartsen $\mathrm{KL}$, Larsen $\mathrm{T}$. Diurnal variation and the effect of feed restriction on plasma and milk metabolites in TMR-fed dairy cows. J Vet Med Ser A Physiol Pathol Clin Med. 2003;50:88-97.

25. Loor JJ, Everts RE, Bionaz M, Dann HM, Morin DE, Oliveira R, et al. Nutrition-induced ketosis alters metabolic and signaling gene networks in liver of periparturient dairy cows. Physiol Genomics. 2007:32:105-16.

26. Schwalm JW, Tucker HA. Glucocorticoids in mammary secretions and blood serum during reproduction and lactation and distributions of glucocorticoids, progesterone, and estrogens in fractions of milk. J Dairy Sci. 1978:61:550-60.

27. Ladewig J, Smidt D. Behavior, episodic secretion of cortisol, and adrenocortical reactivity in bulls subjected to tethering. Horm Behav. 1989;23:344-60

28. Van Uum SHM, Sauvé B, Fraser LA, Morley-Forster P, Paul TL, Koren G. Elevated content of cortisol in hair of patients with severe chronic pain: A novel biomarker for stress. Stress. 2008;11:483-8.

29. Dippel S, Dolezal M, Brenninkmeyer C, Brinkmann J, March S, Knierim U, et al. Risk factors for lameness in freestall-housed dairy cows across two breeds, farming systems, and countries. J Dairy Sci. 2009;92:5476-86.

30. O'Driscoll K, McCabe M, Earley B. Differences in leukocyte profile, gene expression, and metabolite status of dairy cows with or without sole ulcers. J Dairy Sci. 2014;98:1685-95.

31. Almeida PE, Weber PSD, Burton JL, Zanella AJ. Depressed DHEA and increased sickness response behaviors in lame dairy cows with inflammatory foot lesions. Domest Anim Endocrinol. 2008;34:89-99.

32. Walker SL, Smith RF, Jones DN, Routly JE, Morris MJ, Dobson H. The effect of a chronic stressor, lameness, on detailed sexual behaviour and hormonal profiles in milk and plasma of dairy cattle. Reprod Domest Anim. 2010;45:109-17.

33. Regal P, Cepeda A, Fente C. Development of an LC-MS/MS method to quantify sex hormones in bovine milk and influence of pregnancy in their levels. Food Addit Contam Part A. 2012;29:770-9.

34. Negrao JA, Marnet PG. Cortisol, adrenalin, noradrenalin and oxytocin release and milk yield during first milkings in primiparous ewes. Small Rumin Res. 2003:47:69-75.

35. Fukasawa M, Tsukada H, Kosako T, Yamada A. Effect of lactation stage, season and parity on milk cortisol concentration in Holstein cows. Livest Sci. 2008;113:280-4.

36. Breves G, Harmeyer J, Farries E, Hoeller H. Glucocorticoid levels in blood plasma of normal and pre-ketotic cows. J Anim Sci. 1980;50:503-7. 